\title{
PENGARUH MODEL PEMBELAJARAN PREDICT-OBSERVE- EXPLAIN (POE) DAN THINK-TALK-WRITE (TTW) TERHADAP HASIL BELAJAR BIOLOGI DITINJAU DARI KREATIVITAS DAN KEMAMPUAN BERPIKIRANALITIS SISWA
}

\author{
Rifad Nurma Yuliansyah ${ }^{1}$, Mohammad Masykuri ${ }^{2}$, Puguh Karyanto ${ }^{3}$ \\ ${ }^{1}$ Program Studi Magister Pendidikan Sains FKIP Universitas Sebelas Maret \\ Surakarta, 57126, Indonesia \\ assalafrifad@gmail.com \\ ${ }^{2}$ Program Studi Magister Pendidikan Sains FKIP Universitas Sebelas Maret \\ Surakarta, 57126, Indonesia \\ mmasykuri@yahoo.com \\ ${ }^{3}$ Program Studi Magister Pendidikan Sains FKIP Universitas Sebelas Maret \\ Surakarta, 57126, Indonesia \\ karyarina@yahoo.com
}

\begin{abstract}
Abstrak
Penelitian ini menggunakan metode eksperimen. Populasi adalah semua siswa kelas XI SMA Negeri 1 Karangpandan tahun pelajaran 2016/2017. Sampel diambil menggunakan cluster random sampling sejumlah 2 kelas. Kelas XI IPA 2 diberi model pembelajaran dengan Predict-ObserveExplain (POE) dan kelas XI IPA 4 diberi model pembelajaran dengan Think-Talk-Write (TTW). Data dikumpulkan dengan menggunakan tes untuk hasil belajar siswa dan kemampuan berpikir analitis, angket untuk kreativitas siswa, hipotesis diuji dengan uji anacova. Dari analisis data dapat disimpulkan bahwa: 1) ada pengaruh model Predict-Observe-Explain (POE) dan Think-Talk-Write (TTW) terhadap hasil belajar, 2) ada pengaruh kreativitas tinggi dan rendah terhadap hasil belajar, 3) ada pengaruh kemampuan berpikir analisis tinggi dan rendah terhadap hasil belajar, 4) tidak ada interaksi model pembelajaran Think-Talk-Write (TTW) dan model pembelajaran PredictObserve-Explain (POE) dengan kreativitas dikategorikan tinggi, rendah terhadap hasil belajar, 5) tidak ada interaksi model pembelajaran Think-Talk-Write (TTW) dan model pembelajaran PredictObserve-Explain (POE) dengan kemampuan berpikir analitis dikategorikan tinggi, rendah terhadap hasil belajar, 6) ada interaksi kreativitas dan kemampuan berpikir analitis dikategorikan tinggi, rendah terhadap hasil belajar, 7) tidak ada interaksi model pembelajaran Think-Talk-Write (TTW) dan model pembelajaran Predict-Observe-Explain (POE) dengan kretivitas dan kemampuan berpikir analitis dikategorikan tinggi, rendah terhadap hasil belajar.
\end{abstract}

Kata kunci: Predict-Observe-Explain (POE), Think-Talk-Write (TTW), Kemampuan Berpikir Analitis, Kreativitas, Hasil Belajar, Sistem Gerak.

\section{Pendahuluan}

Pembelajaran bukanlah memindahkan pengetahuan dari guru ke siswa, melainkan suatu kegiatan yang memungkinkan siswa secara aktif untuk membangun pengetahuannya sendiri. Peran guru dalam pembelajaran sebagai fasilitator yang membantu siswa dalam mengkontruksi pengetahuan siswa. Pengetahuan dibangun sendiri oleh siswa berdasarkan struktur kognitif yang telah ada pada diri dalam bentuk pengetahuan awal. Siswa yang harus berpikir kritis akan dapat menganalisis, membandingkan, menggeneralisasi, membuat hipotesis sampai dengan membuat kesimpulan dari masalah yang 
ada. Aktivitas yang kreatif dan inovatif dari siswa merupakan faktor penting bagi penentu keberhasilan belajar.

Proses pembelajaran biologi sebagai suatu sistem, pada prinsipnya merupakan kesatuan yang tidak terpisahkan antara komponenkomponen: raw input (peserta didik), instrumental input (masukan instrumental), lingkungan dan outputnya (hasil keluaran). Komponen-komponen tersebut mewujudkan sistem pembelajaran biologi dengan prosesnya berada di pusatnya. Komponen masukan instrumental, yang berupa kurikulum, guru, sumber belajar, media, metode dan sarana prasarana pembelajaran, nampaknya sangat berpengaruh terhadap proses pembelajaran biologi. Proses pembelajaran dalam teori modern, tidak tergantung sekali kepada keberadaan guru (pendidik) sebagai pengelola proses pembelajaran.

Kondisi rendahnya penguasaan pembelajaran sains terutama biologi terjadi di SMA Negeri 1 Karangpandan. Guru belum sepenuhnya melaksanakan pembelajaran Sains sebagai mana hakikatnya. Materi pelajaran cederung diajarakan secara verbal tekstual dan kurang berproses ilmiah. Guru memahami pembelajaran sains hanya sebagai produk, sehingga orientasi pembelajaran hanya menitikberatkan pada kemampuan siswa dalam menguasai produk pembelajaran yang berupa konsep, fakta, teori saja. Akibatnya pembelajaran hanya mengembangkan aspek kongnitif saja sedangkan aspek afektif dan psikomotorik belum berkembang. Pembelajaran yang terjadi belum mengembangkan keterampilan proses dalam melakukan ekplorasi materi pelajaran dan fenomena alam. Siswa menjadi tidak terbiasa mencari, mengolah, dan menemukan informasi. Siswa cenderung senang menghafal pelajaran, sehingga kemampuan siswa dalam mengemukakan pendapat dari pengetahuan yang dimiliki masih sangat rendah. Siswa hanya mampu menghafal suatu materi atau pengetahuan, tetapi belum mampu untuk mengemukakan pendapat dari pengetahuan yang dimiliki. Pengetahuan yang diperoleh karena hafalan tidak bertahan lama dalam pikiran siswa serta kemampuan mengemukakan pendapat masih sangat rendah membuat siswa kurang aktif dan hasil belajar masih kurang.

Rendahnya hasil belajar menjadi indikator kurang berhasilnya kegiatan pembelajaran. Berdasarkan hasil analisis diketahui bahwa kemampuan siswa dalam memecahkan masalah masih rendah, khususnya pada materi Sistem Gerak. Siswa cenderung mengalami kesulitan ketika diberi pertanyaanpertanyaan yang berbentuk pemecahan masalah.

Guna mengatasi permasalahan tersebut, dalam proses pembelajaran guru harus mampu berperan sebagai fasilitator yang dapat memberi peluang, penguatan, stimulus kepada siswa untuk berperan aktif dan menjadikan siswa sebagai subyek belajar. Siswa harus diposisikan sebagai subyek belajar bukan sebagai obyek belajar, sehingga siswa hanya menghafal produk pengetahuan. Guru harus berparadigama bahwa pengetahuan di bentuk oleh siswa secara aktif bukan diterima secara pasif dari guru. Oleh karena itu proses pembelajaran harus menekankan pada peran aktif siswa dalam mengkonstruksi pengetahuan sehingga pembelajaran mengembangkan aspek kongnitif, aspek afektif dan psikomotorik.

Salah satu model pembelajaran yang diasumsikan dapat meningkatkan hasil belajar adalah dengan menggunakan pembelajaran model Think-Talk-Write, yang selanjutnya disingkat TTW. Strategi TTW diperkenalkan Huinker dan Laughlin (1996) terdiri dari tiga fase yaitu fase think, fase talk,dan fase write. Pada fase think siswa diberikan permasalahan 
kemudian siswa memikirkan kemungkinan jawaban dari permasalahan tersebut. Selanjutnya fase talk, pada fase ini siswa bekerja secara berkelompok mendiskusikan permasalahan yang didapat pada fase think. Fase yang ketiga adalah fase write, pada fase ini siswa bekerja secara individu, menuangkan ide-ide yang didapat pada fase talk dan menuliskannya dengan bahasa sendiri hasil diskusinya sehingga siswa lebih. Strategi ini mempunyai kelebihan diantaranya: 1) membantu siswa dalam mengkonstruksi pengetahuannya sendiri sehingga pemahaman konsep siswa menjadi lebih baik, 2) melatih siswa untuk menuliskan hasil diskusinya ke bentuk tulisan secara sistematis sehingga membantu siswa untuk mengkomunikasikan ide-idenya dalam bentuk tulisan. Adapun kekurangan metode ini adalah kurang memperhatikan pengalaman siswa dalam kehidupan sehari-hari.

Model pembelajaran lain yang juga diasumsikan meningkatkan hasil belajar adalah dengan model PredictObserve-Explain, selanjutnya disingkat POE. Menurut White dan Gunstone (dalam Keeratichamroen, 2007) model pembelajaran Predict-Observe

Explain (POE) merupakan model yang efisien untuk menciptakan diskusi para siswa mengenai konsep ilmu pengetahuan. Model pembelajaran ini melibatkan siswa dalam meramalkan suatu fenomena, melakukan observasi melalui demonstrasi, dan akhirnya menjelaskan hasil demonstrasi dan ramalan mereka sebelumnya. Tahapan pembelajaran POE terdiri atas tiga bagian,

pertama predict, kemudian observe, dan yang terakhir adalah explain. Adapun kelebihan model pembelajaran POE dapat digunakan untuk, 1) mampu menjadikan siswa kreataif mendorong siswa mengekplorasi ide-ide dan gagasannya untuk memprediksi dalam memecahakan masalah, 2) mengurangi verbalitas dalam pembelajaran, sehingga siswa dapat berkreativitas secara nyata melalui observasi, 3) membantu siswa memahami materi pelajaran secara lebih bermakna dan mendalam karena dapat membuktikan kebenaran materi, 4) memberikan informasi bagi guru untuk mengetahui cara berpikir siswa,5) mampu menemukan adanya miskonsepsi dalam perkembangan yang dimiliki siswa, 6) melatih siswa untuk melakukan kegiatan diskusi.

Berbagai faktor internal siswa yang berperan penting dalam proses pembelajaran. Faktor internal siswa yang harus diperhatikan dan dikembangkan oleh guru antara lain kreativitas dan kemampuan berpikir analitis. Guru harus mengenal berbagai karaktristik siswa, guru harus menyadari bahwa memiliki kemampuan yang berbeda-beda karena setiap siswa memiliki kecerdasan, minat, kreativitas, motivasi belajar bahkan kemampuan analitis yang berbeda-beda..

Kreativitas sejalan dengan metode pembelajaran yang akan diterapkan yaitu model Predict-Observe-Explain, dan Think-Talk-Write. Metode PredictObserve-Explain lebih menekankan pada kreativitas meramalkan suatu fenomena, melakukan observasi melalui demonstrasi, dan akhirnya menjelaskan hasil demonstrasi dan ramalan mereka sebelumnya. Sedangkan model ThinkTalk-Write menekankan keberanian mengemukakan jawaban permasalahan yang berbeda-beda.

Menurut Munandar (2009), kreativitas adalah kemampuan untuk membuat kombinasi baru, berdasarkan data, informasi atau unsur-unsur yang ada. Hasil yang diciptakantidak selalu hal-hal yang baru, tetapi juga dapat berupa gabungan (kombinasi) dari halhal yang sudah ada sebelumnya. Selain itu, Csikszentmihalyi (dalam Clegg, 2008) menyatakan kreativitas sebagai 
suatu tindakan, ide, atau produk yang mengganti sesuatu yang lama menjadi sesuatu yang baru. Kreativitas penelitian ini dikelompokkan dalam 2 kategori yaitu kreativitas tinggi bagi siswa yang mempunyai nilai tes kreativitas $\geq$ ratarata nilai tes kreativitas seluruh kelas dan kategori kreativitas rendah bagi siswa yang mempunyai nilai tes kreativitas < rata-rata nilai tes kreativitas seluruh kelas.

Selain kreativitas faktor lain yang perlu diperhatikan adalah kemampuan berpikir analisis karena dapat mendukung proses keaktifan siswa sehingga pembelajaran menjadi lebih baik. Kemampuan berpikir analisis selama ini belum diperhatikan oleh guru. Kemampuan berpikir analisis sangat dibutuhkan pada materi sistem gerak misalnya menginterpretasi data hasil eksperimen.

Kemampuan berpikir analisis dikelompokkan dalam 2 kategori yaitu kemampuan berpikir analisis tinggi bagi siswa yang mempunyai nilai kemampuan berpikir analisis $\geq$ rata-rata nilai kemampuan berpikir analisis seluruh kelas dan kategori kemampuan berpikir analisis rendah bagi siswa yang mempunyai nilai kemampuan berpikir analisis < rata-rata nilai kemampuan berpikir analisis seluruh kelas.

Berdasarkan standar isi kurikulum SMA materi sistem gerak manusia diajarkan di SMA kelas XI semester I pada mata pelajaran Biologi. Pada penelitian ini peneliti mengambil materi sistem gerak telah mengacu standar isi kompetensi dasar 3.1 yang berisi: menjelaskan keterkaitan antara struktur, fungsi, dan proses serta kelainan/penyakit yang dapat terjadi pada sistem gerak pada manusia. Dari analisis kompetensi dasar tersebut kemudian dijabarkan kedalam indikator pembelajaran, tujuan pembelajaran dan mengembangkan materi pembelajaran.

\section{Metode Penelitian}

Jenis penelitian yang digunakan dalam penelitian ini adalah penelitian quasi eksperimen atau penelitian semu, yaitu penelitian yang dilakukan dengan sengaja mengusahakan timbulnya variabel-variabel.

Penelitian ini dilakukan dengan membagi subjek menjadi 2 kelompok (kelas) yang dibedakan menjadi 2 kategori kelas eksperimen. Pada kelas eksperimen 1 dikenai perlakuan model pembelajaran Think-Talk-Write (TTW), sedangkan pada kelas eksperimen 2 akan dikenai perlakuan model pembelajaran Predict-Observe-Explain (POE).

Sebelum perlakuan diberikan, terlebih dahulu masing-masing kelompok (kelas) dipastikan memiliki kemampuan awal yang sama. Tahap akhir dari penelitian ini adalah masingmasing kelompok diberikan test untuk mengukur tingkat prestasi setelah mendapat perlakuan. Data ekperimen yang diperoleh kemudian diolah menggunakan uji ststistik analisis variasi tiga jalan dengan desain factorial (2x2x2) yang dapat digambarkan pada tabel 3.2 berikut.

\begin{tabular}{|c|c|c|c|c|c|}
\hline \multicolumn{6}{|c|}{ Kreativitas (B) } \\
\hline & & \multicolumn{2}{|c|}{ Kreativitas tinggi $\left(\mathrm{B}_{1}\right)$} & \multicolumn{2}{|c|}{ Kreativitas rendah $\left(\mathrm{B}_{2}\right)$} \\
\hline & & $\begin{array}{l}\text { Kemampuan } \\
\text { berpikir } \\
\text { analitis } \\
\text { tinggi } \\
\left(\mathrm{C}_{1}\right)\end{array}$ & $\begin{array}{l}\text { Kemampuan } \\
\text { berpikir } \\
\text { analitis } \\
\text { rendah } \\
\left(\mathrm{C}_{2}\right)\end{array}$ & $\begin{array}{l}\text { Kemampuan } \\
\text { berpikir } \\
\text { analitis } \\
\text { tinggi } \\
\left(\mathrm{C}_{1}\right) \\
\end{array}$ & $\begin{array}{l}\text { Kemampu } \\
\text { an berpikir } \\
\text { analitis } \\
\text { rendah } \\
\left(\mathrm{C}_{2}\right) \\
\end{array}$ \\
\hline \multirow[b]{2}{*}{$\begin{array}{c}\text { Model } \\
\text { pembelajaran } \\
\text { (A) }\end{array}$} & $\begin{array}{l}\text { Model } \\
\text { pembelajaran } \\
\text { Talk-Think- } \\
\text { Write (TTW) } \\
\left(\mathrm{A}_{1}\right)\end{array}$ & $\mathrm{A}_{1} \mathrm{~B}_{1} \mathrm{C}_{1}$ & $\mathrm{~A}_{1} \mathrm{~B}_{1} \mathrm{C}_{2}$ & $\mathrm{~A}_{1} \mathrm{~B}_{2} \mathrm{C}_{1}$ & $\mathrm{~A}_{1} \mathrm{~B}_{2} \mathrm{C}_{2}$ \\
\hline & \begin{tabular}{|l|} 
Model \\
pembelajaran \\
Predict- \\
Observe- \\
Explain \\
$(\mathrm{POE})$ \\
$\left(\mathrm{A}_{2}\right)$ \\
\end{tabular} & $\mathrm{A}_{2} \mathrm{~B}_{1} \mathrm{C}_{1}$ & $\mathrm{~A}_{2} \mathrm{~B}_{1} \mathrm{C}_{2}$ & $\mathrm{~A}_{2} \mathrm{~B}_{2} \mathrm{C}_{1}$ & $\mathrm{~A}_{2} \mathrm{~B}_{2} \mathrm{C}_{2}$ \\
\hline
\end{tabular}

Populasi dalam penelitian ini adalah seluruh siswa SMA Negeri 1 Karangpandan kelas XI IPA semester ganjil yang terdiri dari 4 kelas

Sampel dalam penelitian ini akan diambil 2 kelas dari 4 kelas, yaitu kelas XI IPA sebagai kelompok kelas pertama dengan menggunakan model 
pembelajaran Think-Talk-Write (TTW) dan kelompok kelas kedua model pembelajaran (Predict-Observe-Explain( POE). Penentuan sampel yang digunakan adalah Clutser random sampling, dimana setiap anggota populasi mempunyai kesempatan yang sama untuk dijadikan sampel.

Variabel bebas dalam penelitian ini adalah pembelajaran model POE dan TTW. Sedangkan yang menjadi variabel moderator adalah kreativitas dan kemampuan berpikir analitis sebagai yang dikatagorikan tinggi dan rendah. Untuk variabel terikat pada penelitian ini adalah hasil belajar pada materi sistem gerak manusia

Pengambilan data pada penelitian ini menggunakan beberapa teknik yaitu:

1. Tes, merupakan suatu teknik yang digunakan dalam rangka melakukan kegiatan pengukuran, yang bertujuan mengukur tingkat kemampuan seseorang (Widoyoko, 2010: 45). Tes dalam penelitian ini adalah tes hasil belajar aspek kognitif dan psikomotor.

2. Observasi, adalah suatu proses pengamatan secara sistematis mengenai berbagai fenomena untuk mencapai tujuan tertentu (Arifin, 2009: 152). Observasi digunakan untuk mengukur aspek afektif dan psikomotor.

3. Angket, adalah suatu daftar pertanyaan yang harus dijawab oleh responden tentang dirinya atau hal yang diketahuinya (Masidjo, 2010: 70). Angket digunakan untuk memperoleh data kreativitas, kemampuan berpikir analitis dan hasil belajar aspek afektif.

F. Instrumen Penelitian

Instrumen yang digunakan untuk mendukung penelitian meliputi:

1. Instrumen Pelaksanaan Penelitian, yang terdiri dari: Silabus, RPP (Rencana Pelaksanaan

LKS(Lembar Kerja Siswa)

2. Instrumen Pengambilan Data
Tes hasil belajar, digunakan untuk mengukur hasil belajar siswa dan kemampuan berpikir analitis pada materi system pencernaan. Hasil belajar yang diukur menggunakan tes adalah aspek kognitif.

Angket digunakan untuk mengukur kreativitas siswa yang meliputi aktivitas yang meliputi visual activities, oral activities, listening activities, writing activities, drawing activities, motor activities, mental activities, dan emotional activities

G. Uji Coba Instrumen

Uji validitas yang digunakan dalam penelitian ini adalah validitas konstruk (Construct Validity). Menurut Jack R. Fraenkel (dalam Siregar 2010:163) validitas konstruk merupakan yang terluas cakupannya dibanding dengan validitas lainnya, karena melibatkan banyak prosedur termasuk validitas isi dan validitas kriteria. Uji Validitas digunakan rumus korelasi Product Moment sebagai berikut.

$r_{x y}=\frac{n\left(\sum X Y\right)-\left(\sum X\right)\left(\sum Y\right)}{\sqrt{\left[n\left(\sum X^{2}\right)-\left(\sum X\right)^{2} \mid n\left(\sum Y^{2}\right)-\left(\sum Y\right)^{2}\right]}}$

Dimana: $r_{x y}=$ koefisien korelasi suatu butir/item

$\mathrm{N}=$ jumlah subyek

$\mathrm{X}=$ skor suatu butir/item

$\mathrm{Y}=$ skor total (Arikunto, 2005: 72)

$\begin{array}{cc}\text { Uji reliabilitas digunkaan uji } \\ \text { konsistensi } & \text { internal dengan }\end{array}$ menggunakan rumus Alpha Cronbach sebagai berikut.

$r_{11}=\left[\frac{k}{k-1}\right]\left[1-\frac{\sum \sigma_{b}^{2}}{V_{t}^{2}}\right]$,

(Arikunto, 1999: 193)

Dimana:

$r_{11} \quad=$ reliabilitas instrumen

$\mathrm{k} \quad=$ banyaknya butir pertanyaan

atau

banyaknya soal 
$\sum \sigma_{b}^{2}=$ jumlah varian butir/item

$V_{t}^{2}=\quad$ varian total

Kriteria suatu instrumen

penelitian dikatakan reliabel dengan menggunakan teknik ini, bila koefisien reliabilitas $\left(r_{11}\right)>0,6$.

Keterangan :

0,81-1,00 : Sangat Tinggi

0,61-0,80 : Tinggi

0,41-0,60 : Cukup

0,21-0,40 : Rendah

Negatif-0,20 : Sangat Rendah

H. Teknik Analisis Data

Uji normalitas untuk mengetahui sampel penelitian berasal dari populasi yang berdistribusi normal atau tidak. Uji normalitas dalam penelitian ini menggunakan uji Liliefors dengan bantuan program PASW dengan taraf signifikasi $\alpha=5 \%$. Jika probabilitas (sig) $>\alpha$, maka $H_{0}$ diterima artinya data normal. Jika probabilitas (sig) $<\alpha$, maka $H_{0}$ ditolak artinya data tidak normal.

Uji homogenitas digunakan untuk mengetahui sampel berasal dari populasi yang homogen atau tidak. Uji homogenitas dalam penelitian ini menggunakan bantuan program SPSS 18 dengan taraf signifikasi $\alpha=5 \%$. Jika probabilitas (sig) $>\alpha$, maka $H_{0}$ diterima artinya data homogen. Jika probabilitas $(\operatorname{sig})<\alpha$, maka $H_{0}$ ditolak artinya data tidak homogen. Jika uji homogenitas terpenuhi, maka analisis uji selanjutnya adalah uji analisis variansi (anacova) dapat dilakukan.

Pengujian hipotesis dengan analisis varian (anacova) tiga jalan factorial $2 \times 2 \times 2$ isi sel tidak sama pada taraf signifikasi $\alpha=0,05$ menggunakan bantuan software SPSS 18.

Uji lanjut anava merupakan tindak lanjut jika menunjukkan bahwa $\mathrm{H}_{0}$ ditolak, tujuan dari uji lanjutan anava adalah untuk melakukan pengecekan terhadap rerata setiap pasangan kolom, baris, dan pasangan sel sehingga diketahui bagian mana sajakah terdapat rerata yang berbeda. Uji lanjut anava dilakukan dengan menggunakan Analysis of Mean (ANOM)

\section{Hasil Penelitian dan Pembahasan}

Data dalam penelitian ini diperoleh dari kelas XI IPA 2 sebagai kelas eksperimen I dengan model POE dan kelas XI IPA 4 sebagai kelas eksperimen II dengan model TTW di SMA Negeri 1 Karangpandan Tahun Pelajaran 2016/2017. Data yang diperoleh meliputi: nilai tes kemampuan berpikir analisis, angket kreativitas, dan nilai tes hasil belajar siswa mata pelajaran Biologi pokok bahasan sistem gerak.

1. Data Kreativitas

Data kreativitas diperoleh dari isian skor angket kreativitas yang dikelompokkan dalam 2 kategori, yaitu kreativitas tinggi bagi siswa yang mempunyai skor angket kreativitas $\geq$ rata-rata skor angket kreativitas seluruh kelas dan kategori kreativitas rendah bagi siswa yang mempunyai skor angket kreativitas < rata-rata nilai tes kreativitas seluruh kelas. Perhitungan kategori pembagian kelompok siswa dapat dilihat pada lampiran. Dengan menggunakan kriteria tersebut dari 80 siswa, terdapat 37 siswa mempunyai kreativitas tinggi dan 43 siswa mempunyai kreativitas rendah. Secara rinci disajikan dalam Tabel 4.1 berikut

Tabel 4.1 Deskripsi Data Kreativitas siswa

\begin{tabular}{ccccccc}
\hline Model & Kreativitas & N & Mean & sd & Minimum & Maximum \\
\hline POE & Tinggi & 17 & 80,4 & 5,2 & 74 & 90 \\
\cline { 2 - 7 } & Rendah & 23 & 67,2 & 4,9 & 55 & 72 \\
\hline \multirow{2}{*}{ TTW } & Tinggi & 20 & 79,5 & 5,3 & 74 & 90 \\
\cline { 2 - 7 } & Rendah & 20 & 66,9 & 4,6 & 55 & 72 \\
\hline
\end{tabular}

Distribusi frekuensi skor angket kreativitas siswa pada kelas yang menggunakan model pembelajaran $\mathrm{POE}$ 
disajikan pada Tabel 4.2

Tabel 4.2 Distribusi Frekuensi Skor Angket Kreativitas pada Kelas yang Menggunakan Model

\begin{tabular}{cccccc}
\multicolumn{6}{c}{ POE } \\
\hline \multicolumn{2}{c}{ Nilai } & Frekuensi & Nilai Tengah & $\begin{array}{c}\text { Frekuensi } \\
\text { Kumulatif }\end{array}$ & $\begin{array}{c}\text { Frekuensi } \\
\text { Persen }(\%)\end{array}$ \\
\hline 55 & -60 & 3 & 57,5 & 3 & 7,5 \\
61 & -66 & 4 & 63,5 & 7 & 10 \\
67 & -72 & 16 & 69,5 & 23 & 40 \\
73 & -78 & 8 & 75,5 & 31 & 20 \\
79 & -84 & 5 & 81,5 & 36 & 12,5 \\
85 & -90 & 4 & 87,5 & 40 & 10 \\
\hline
\end{tabular}

Tabel di atas di buat histogram skor angket kreativitas pada kelas yang menggunakan model POE yang dapat dilihat pada Gambar 4.1

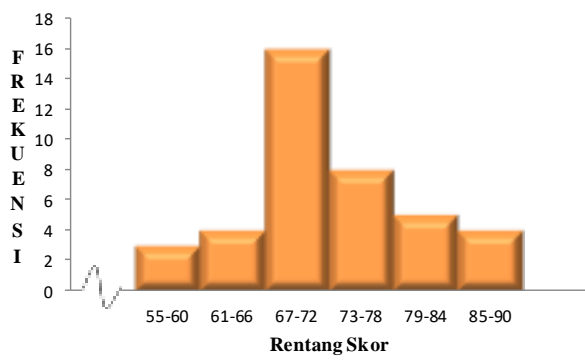

Gambar 4.1 Histogram Skor Angket Kreativitas Siswa pada Kelas yang Menggunakan Model POE

Distribusi frekuensi skor angket kreativitas siswa pada kelas yang menggunakan model pembelajaran TTW dapat dilihat pada Tabel 4.3.

Tabel 4.3 Distribusi Frekuensi Kreativitas pada

\begin{tabular}{cccccc}
\multicolumn{5}{c}{ Kelas yang Menggunakan Model TTW } \\
\hline \multicolumn{2}{c}{ Nilai } & Frekuensi & Nilai Tengah & $\begin{array}{c}\text { Frekuensi } \\
\text { Kumulatif }\end{array}$ & $\begin{array}{c}\text { Frekuensi } \\
\text { Persen }(\%)\end{array}$ \\
\hline 55 & -60 & 2 & 59,5 & 2 & 5 \\
61 & -66 & 5 & 65,5 & 7 & 12,5 \\
67 & -72 & 13 & 71,5 & 20 & 32,5 \\
73 & -78 & 11 & 77,5 & 31 & 27,5 \\
79 & -84 & 5 & 83,5 & 36 & 12,5 \\
85 & -90 & 4 & 89,5 & 40 & 10 \\
\hline
\end{tabular}

Untuk memperjelas distribusi skor di atas, dibuat histogram tentang distribusi skor angket kreativitas pada kelas yang memggunakan model TTW pada Gambar 4.2

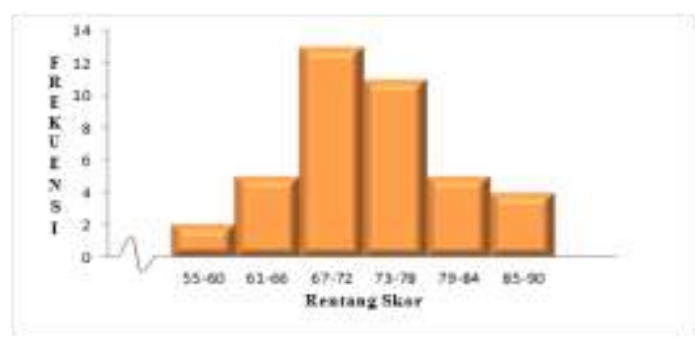

Gambar 4.2 Histogram Skor Angket Kreativitas Siswa pada Kelas yang Menggunakan Model TTW

\section{Data Kemampuan Berpikir Analitis} Siswa

Dalam penelitian ini data kemampuan berpikir analitis siswa diperoleh dari nilai pada materi pokok sistem gerak. Kemampuan berpikir analitis siswa dikategorikan menjadi dua, yaitu kemampuan berpikir analitis tinggi dan kemampuan berpikir analitis rendah.

Deskripsi data kemampuan berpikir analitis dapat dilihat pada Tabel 4.4

Tabel 4.4 Deskripsi Data Kemampuan Berpikir

\begin{tabular}{llcccll}
\multicolumn{7}{c}{ Analitis Siswa } \\
\multirow{2}{*}{ Model } & Kemampuan & \multirow{2}{*}{ N } & Mean & sd & Minimum & Maximum \\
& Berpikir Analitis & & & & & \\
\hline \multirow{2}{*}{ POE } & Tinggi & 18 & 76,7 & 5,3 & 70 & 87 \\
& Rendah & 22 & 61,9 & 6,7 & 40 & 67 \\
\hline \multirow{2}{*}{ TTW } & Tinggi & 24 & 72,2 & 5,8 & 67 & 87 \\
& Rendah & 16 & 58,5 & 4,8 & 47 & 63 \\
\hline
\end{tabular}

Distribusi frekuensi niali hasil tes kemampuan berpikir analitis siswa pada kelas yang menggunakan model POE tersaji pada Tabel 4.5

Tabel 4.5 Distribusi Frekuensi Kemampuan Berpikir Analitis pada Kelas yang Menggunakan Model POE

\begin{tabular}{ccccc}
\hline Nilai & Frekuensi & Nilai Tengah & $\begin{array}{c}\text { Frekuensi } \\
\text { Kumulatif }\end{array}$ & $\begin{array}{c}\text { Frekuensi } \\
\text { Persen (\%) }\end{array}$ \\
\hline $40-47$ & 1 & 43,5 & 2 & 2,5 \\
$48-55$ & 2 & 51,5 & 7 & 5 \\
$56-63$ & 10 & 59,5 & 20 & 25 \\
$64-71$ & 12 & 67,5 & 31 & 30 \\
$72-79$ & 8 & 75,5 & 36 & 20 \\
$80-87$ & 7 & 83,5 & 40 & 17,5 \\
\hline
\end{tabular}




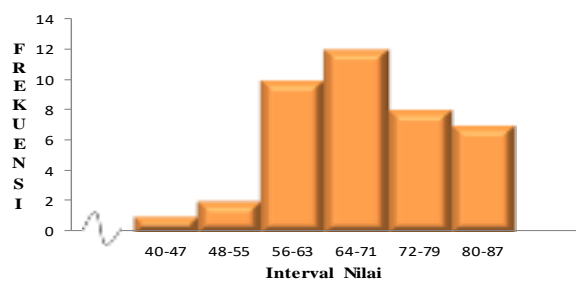

Gambar 4.3 Histogram Nilai Kemampuan Berpikir Analitis Siswa pada Kelas yang Menggunakan Model POE

Tabel 4.6 Distribusi Frekuensi Niali Hasil Tes Kemampuan Berpikir Analitis Pada Kelas yang Menggunakan Model TTW

\begin{tabular}{cccccc}
\hline Nilai & Frekuensi & Nilai Tengah & $\begin{array}{c}\text { Frekuensi } \\
\text { Kumulatif }\end{array}$ & $\begin{array}{c}\text { Frekuensi } \\
\text { Persen }(\%)\end{array}$ \\
\hline $47-53$ & 3 & 50 & 3 & 7,5 \\
$54-60$ & 8 & 57 & 11 & 20 \\
$61-67$ & 11 & 64 & 22 & 27,5 \\
$68-74$ & 9 & 71 & 31 & 22,5 \\
$75-81$ & 7 & 78 & 38 & 17,5 \\
$82-88$ & 2 & 85 & 40 & 5 \\
\hline
\end{tabular}

Untuk memperjelas distribusi skor di atas, dibuat histogram tentang distribusi nilai hasil tes kemampuan berpikir analitis pada kelas yang memggunakan model TTW pada Gambar 4.4

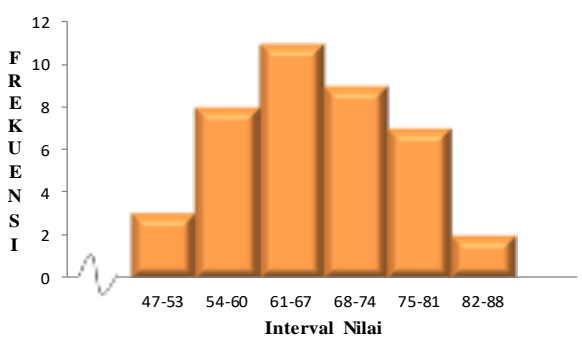

Gambar 4.4 Histogram Nilai Kemampuan Berpikir Analitis Siswa pada Kelas yang Menggunakan Model TTW

\section{Hasil Belajar Biologi}

Deskripsi hasil belajar biologi dengan model POE tersaji pada tabel 4.7 dan tabel 4.8 berikut.

Tabel 4.7 Deskripsi Data Hasil Belajar

\begin{tabular}{llllll}
\hline Model & $\mathrm{N}$ & Mean & sd & Minimum & Maximum \\
\hline POE & 40 & 75,4 & 7,4 & 60 & 90 \\
TTW & 40 & 69,2 & 9,7 & 50 & 88 \\
\hline
\end{tabular}

Tabel 4.8 Distribusi Frekuensi Nilai Hasil Belajar Belajar Biologi pada Kelas yang Menggunakan Model POE

\begin{tabular}{cccccc}
\hline \multicolumn{2}{c}{ Nilai } & Frekuensi & Nilai Tengah & $\begin{array}{c}\text { Frekuensi } \\
\text { Kumulatif }\end{array}$ & $\begin{array}{c}\text { Frekuensi } \\
\text { Persen }(\%)\end{array}$ \\
\hline 57 & -62 & 4 & 62,5 & 4 & 10 \\
63 & -68 & 2 & 68,5 & 6 & 5 \\
69 & -74 & 11 & 74,5 & 17 & 27,5 \\
75 & -80 & 15 & 80,5 & 32 & 37,5 \\
81 & -86 & 5 & 86,5 & 37 & 12,5 \\
87 & -92 & 3 & 92,5 & 40 & 7,5 \\
\hline
\end{tabular}

Untuk memperjelas distribusi nilai di atas, dibuat histogram tentang distribusi nilai hasil belajar Biologi pada kelas yang memggunakan model POE pada Gambar 4.5

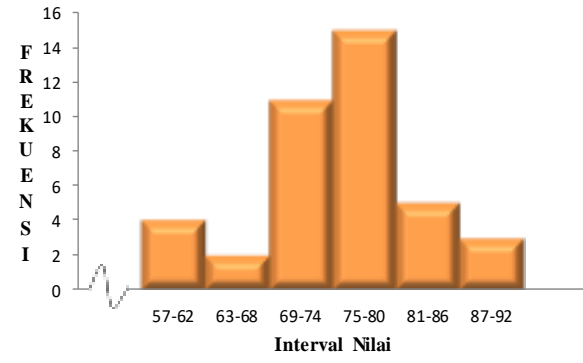

Gambar 4.5 Histogram Nilai Hasil Belajar Belajar Biologi pada Kelas yang Menggunakan Model POE

Sedangkan distribusi frekuensi nilai hasil belajar Biologi siswa pada kelas yang menggunakan model TTW disajikan pada Tabel 4.9.

Tabel 4.9 Distribusi Frekuensi Nilai Hasil Belajar belajar Biologi Pada Kelas yang Menggunakan

\begin{tabular}{cccccc}
\multicolumn{6}{c}{ Model TTW } \\
\hline \multicolumn{2}{c}{ Nilai } & Frekuensi & Nilai Tengah & $\begin{array}{c}\text { Frekuensi } \\
\text { Kumulatif }\end{array}$ & $\begin{array}{c}\text { Frekuensi } \\
\text { Persen (\%) }\end{array}$ \\
\hline 49 & -55 & 4 & 52,5 & 4 & 10 \\
56 & -62 & 4 & 59,5 & 8 & 10 \\
63 & -69 & 10 & 66,5 & 18 & 25 \\
70 & -76 & 12 & 73,5 & 30 & 30 \\
77 & -83 & 3 & 80,5 & 33 & 7,5 \\
84 & -90 & 7 & 87,5 & 40 & 17,5 \\
\hline
\end{tabular}

Untuk memperjelas distribusi nilai di atas, dibuat histogram tentang distribusi nilai hasil belajar Biologi pada kelas yang memggunakan model TTW pada Gambar 4.6 


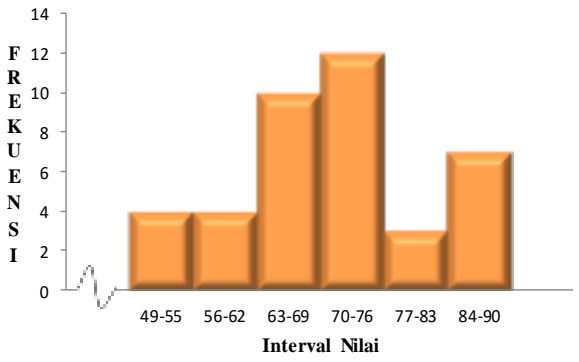

Gambar 4.6 Histogram Nilai Hasil Belajar Belajar Biologi pada Kelas yang Menggunakan Model TTW

\section{Pengujian Prasyarat Analisis 1. Uji Normalitas}

Uji normalitas data dalam penelitian ini menggunakan software SPSS versi 18 yang ringkasan hasilnya disajikan pada Tabel 4.10

Tabel 4.10 Hasil Uji Normalitas Data Hasil Belajar

\begin{tabular}{clccc}
\hline No & \multicolumn{1}{c}{ Data } & Signifikansi & Keputusan & Distrubusi Data \\
\hline 1. & Kreativitas & 0,079 & Ho: diterima & Normal \\
2. & Kreativitas model POE & 0,200 & Ho: diterima & Normal \\
3. & Kreativitas Model TTW & 0,200 & Ho: diterima & Normal \\
4. & Berpikir Analitis & 0,070 & Ho: diterima & Normal \\
5. & Berpikir Analitis Model POE & 0,200 & Ho: diterima & Normal \\
6. & Berpikir Analitis Model TTW & 0,200 & Ho: diterima & Normal \\
7. & Hasil Belajar & 0,091 & Ho: diterima & Normal \\
8. & Hasil Belajar model POE & 0,200 & Ho: diterima & Normal \\
9 & Hasil Belajar model TTW & 0,200 & Ho: diterima & Normal \\
\hline
\end{tabular}

\section{Uji Homogenitas}

Uji homogenitas yang peneliti gunakan adalah metode uji $\mathrm{F}$. Adapun sebagai pendukung keputusan dilakukan juga uji Levene menggunakan perhitungan dengan SPSS 18. Hasil uji homogenitas disajikan dalam Tabel 4.11

Tabel 4. 11 Hasil Uji Homogenitas antar Kelompok Data Hasil Belajar

\begin{tabular}{clcc}
\hline No & \multicolumn{1}{c}{ Aspek } & Sig & Kesimpulan Uji \\
\hline 1 & Model Pembelajaran & 0,136 & Homogen \\
2. & Kreativitas & 0,411 & Homogen \\
3. & Kemampuan Berpikir Analitis & 0,098 & Homogen \\
\hline
\end{tabular}

Berdasarkan hasil penelitian yang tertera pada Tabel 4.11 di atas, diketahui bahwa setiap uji perbandingan dua varian diperoleh sig $>0,05$, sehingga diperoleh kesimpulan Ho diterima. Hal ini berarti bahwa homogenitas data hasil belajar berdasarkan faktor Metode, tingkat kreativitas sisa dan kategori kemampuan berpikir analitis terpenuhi, sehingga uji selanjutnya, yaitu uji Anacova dapat dilakukan.

\section{Pengujian Hipotesis Penelitian 1. Uji Analisis Variansi}

Pengujian hipotesis pada penelitian ini menggunakan anacova tiga jalan. Adapun rangkuman hasil analisis variansi tiga jalan dengan frekuensi sel tidak sama dapat dicermati pada Tabel 4.12

Tabel 4.12 Rangkuman ANAVA Tiga Jalan Hasil Belajar Biologi

\begin{tabular}{clc}
\hline No & \multicolumn{1}{c}{ Aspek } & Sig \\
\hline 1 & Model Pembelajaran & 0,020 \\
2. & Kreativitas & 0,011 \\
3. & Kemampuan Berpikir Analitis & 0,021 \\
4 & Model + Kreativitas & 0,085 \\
5 & Model + Kemampuan Berpikir Analitis & 0,138 \\
6 & Kreativitas +Kemampuan Berpikir Analitis & 0,008 \\
7 & Model + Kreativitas+Kemampuan Berpikir Analitis & 0,496 \\
\hline
\end{tabular}

\section{Uji Lanjut Analisis Variansi}

Uji hipotesis pada aspek hasil belajar dengan menggunakan model pembelajaran POE dan TTW menghasilkan $\mathrm{H}_{0}$ ditolak, yaitu $\mathrm{H}_{0} \mathrm{~A}$. Hasil uji lanjut anava hipotesis $\mathrm{H}_{1} \mathrm{~A}$ yang menyatakan ada pengaruh model pembelajaran Think-Talk-Write (TTW) dan model pembelajaran PredictObserve-Explain (POE) terhadap hasil belajar disajikan pada Tabel 4.13 sebagai berikut:

\begin{tabular}{cccc}
\multicolumn{4}{c}{ Tabel 4.13 Uji Lanjut Anava Hasil Belajar } \\
\hline Model Pembelajaran & Mean & $\mathrm{N}$ & Std. Deviation \\
\hline POE & 75,00 & 40 & 7,86 \\
TTW & 70,27 & 40 & 10,19 \\
Total & 72,64 & 80 & 9,35 \\
\hline
\end{tabular}

Uji hipotesis pada aspek kreativitas menghasilkan $\mathrm{H}_{0}$ ditolak berarti $\mathrm{H}_{1} \mathrm{~B}$ diterima dengan demikian dapat dinyatakan ada pengaruh kreativitas tinggi dan rendah terhadap hasil belajar disajikan pada tabel 4.14 berikut. 
Tabel 4.14 Uji Lanjut Anava pada Hasil Belajar Ditinjau dari Kreativitas

\begin{tabular}{llcc} 
Hasil Belajar & & & \\
\hline Kreativitas & Mean & $\mathrm{N}$ & Std. Deviation \\
\hline Tinggi & 75,68 & 37 & 8,02 \\
Rendah & 70,02 & 43 & 9,70 \\
\hline Total & 72,64 & 80 & 9,35 \\
\hline
\end{tabular}

\section{Uji hipotesis pada aspek} kemampuan berpikir analitis menghasilkan $\mathrm{H}_{0}$ ditolak, yaitu $\mathrm{H}_{0} \mathrm{C}$. Hasil uji lanjut anava hipotesis $\mathrm{H}_{1} \mathrm{C}$ yang menyatakan ada pengaruh kemampuan berpikir analitis tinggi dan rendah terhadap hasil belajar, disajikan pada Tabel 4.15 sebagai berikut:

Tabel 4.15 Uji Lanjut Anava pada Hasil Belajar Ditinjau dari Kemampuan Berpikir Analitis

\begin{tabular}{lccc} 
Hasil Belajar & & & \\
\hline Berpikir Analitis & Mean & N & Std. Deviation \\
\hline Tinggi & 75,68 & 34 & 7,47 \\
Rendah & 70,39 & 46 & 10,02 \\
\hline Total & 72,64 & 80 & 9.35 \\
\hline
\end{tabular}

Uji hipotesis interaksi antara kreativitas dan kemampuan berpikir analitis menghasilkan $\mathrm{H}_{0}$ ditolak, yaitu $\mathrm{H}_{0} \mathrm{BC}$. Hasil uji lanjut anava hipotesis $\mathrm{H}_{1} \mathrm{BC}$ yang menyatakan ada interaksi kreativitas dan kemampuan berpikir analitis dikategorikan tinggi, rendah terhadap hasil belajar disajikan pada Tabel 4.16 sebagai berikut:

Tabel 4.16 Uji Lanjut Anava pada Hasil Belajar Ditinjau dari Kemampuan Kreativitas dan Berpikir Analitis

\begin{tabular}{llccc} 
Hasil Belajar & \multicolumn{3}{l}{} \\
\hline Kreativitas & Berpikir Analitis & Mean & Std. Deviation & $\mathrm{N}$ \\
\hline \multirow{2}{*}{ Tinggi } & Tinggi & 75,44 & 7,47 & 18 \\
& Rendah & 75,89 & 8,71 & 19 \\
& Total & 75,68 & 8,02 & 37 \\
\hline \multirow{2}{*}{ Rendah } & Tinggi & 75,94 & 7,71 & 16 \\
& Rendah & 66,52 & 9,14 & 27 \\
& Total & 70,02 & 9,70 & 43 \\
\hline \multirow{2}{*}{ otal } & Tinggi & 75,68 & 7,47 & 34 \\
& Rendah & 70,39 & 10,02 & 46 \\
& Total & 72,64 & 9,352 & 80 \\
\hline
\end{tabular}

\section{Kesimpulan dan Rekomendasi}

Sesuai dengan tujuan penelitian, hasil penelitian, dan pembahasan pada bab sebelumnya, maka dalam penelitian ini dapat disimpulkan sebagai berikut:

1. Ada pengaruh model PredictObserve-Explain (POE) dan ThinkTalk-Write (TTW) terhadap hasil belajar. Siswa yang diajarkan dengan menggunakan model Predict-Observe-Explain (POE) mendapatkan hasil lebih baik daripada siswa yang diajarkan dengan model Think-Talk-Write (TTW).

2. Ada pengaruh kreativitas tinggi dan rendah hasil belajar. Secara umum siswa yang memiliki kreativitas tinggi memperoleh hasil belajar yang lebih tinggi daipada siswa yang memiliki kreativitas rendah rendah.

3. Ada pengaruh kemampuan berpikir analisis tinggi dan rendah ditunjukkan dengan adanya perbedaan rata-rata hasil belajar.

4. Tidak ada interaksi model pembelajaran Think-Talk-Write (TTW) dan model pembelajaran Predict-Observe-Explain (POE) dengan kreativitas dikategorikan tinggi, rendah.

5. Tidak ada interaksi model pembelajaran Think-Talk-Write (TTW) dan model pembelajaran Predict-Observe-Explain (POE) dengan kemampuan berpikir analitis dikategorikan tinggi, rendah terhadap hasil belajar tidak terbukti.

6. Ada interaksi kreativitas dan kemampuan berpikir analitis dikategorikan tinggi, rendah terhadap hasil belajar. Siswa dengan kemampuan berpikir analisis tinggi akan memperoleh hasil belajar yang baik dengan kreativitas tinggi maupun rendah.

7. Tidak ada interaksi model pembelajaran Think-Talk-Write (TTW) dan model pembelajaran Predict-Observe-Explain (POE) dengan kretivitas dan kemampuan berpikir analitis dikategorikan 
tinggi, rendah terhadap hasil belajar.

\section{Daftar Pustaka}

Adebayo, Famakinwa et al.(2015). Generative and Predict-ObserveExplain Instructional Strategies: Towards Enhancing Basic Science Practical Skills of Lower Primary School Pupil . International Journal of Elementary Education, vol 4(4), 86-92

Ayvacı, Şevki Hakan .(2013). Investigating The Effectiveness of PredictObserve-Explain Strategy On Teaching Photo Electricity Topic. Turkey Journal of Baltic Science Education, Vol. 12 (5). 548-564.

Coştu,Bayram .) (2008). Learning Science Through The PDEODE Teaching Strategy: Eurasia Journal of Mathematics, Science \& Technology Education.Vol 4(1).3-9

Costu, Baryam. et al .( 2011). Investigating The Effectiveness Of A POE-Based Teaching Activity On Students Understanding Of Condensation. Department Chemistry Education Journal, Dokuz Eylul University, Vol 40, 47-67.

Dimyati, Mudjiono. (2006). Belajar Dan Pembelajaran. Jakarta : Rineke Cipta

Dimyati Dan Mujdiono,(2009),Belajar Dan Pembelajaran.Jakarta : Penerbit Rineka Cipta,

Dunn, Michael.(2013).Comparing Two Story-Writing Mnemonic Strategies: A Randomized Control Trial Study. International Journal Of Special Education, Washington State University, Vol 28( 3), 20-31

Helping Students Make Sense Of Everyday Situations .(2008). Karadeniz Technical University, Trabzon, TURKEY : Eurasia Journal Of Mathematics, Science \& Technology Education, Vol. 4(1), 3-9
Hilario, Jose.S.(2015). The Use of PredictObserve-Explain-Explore (POEE) as a New Teaching Strategy in General Chemistry-Laboratory Development of Predict-observeexplain Strategy for Teaching Flow Injection at Undergraduate Chemistry . International Journal of Education and Research,vol 3(2), $37-48$

Kearney, Matthew Dan David F. Treagust. (2000). An Investigation On The Classroom Use of PredictionObservation-Explanation Computer Task Designed To Elicit And Promote Discussion Of Student's Conception Of Force And Motion. Paper Presented At The 2000 National Association For Research In Science Technical Meeting, April 28-31, 2000, New Orleans, LA, USA.

Kibirige, Israel. et al. (2014). The Effect of Predict-Observe-Explain Strategy on Learners' Misconceptions about Dissolved Salts. Mediterranean Journal of Social Sciences MCSER Publishing, Vol 12 (5), 2039-2117

Listiana, Lina .(2015). Empowering Students' Meta Cognitive Skills Through New Teaching Strategy (Group Investigation Integrated With Think TalK Write) In Biology Classroom. Journal of Baltic science education, Vol 15(3),391400

Nana. Sudjana Dan Ibrahim. (2004). Penelitian Dan Penilaian Pendidikan. Bandung : Sinar Baru Algesindo

Nana Sudjana. (2009). Media Pengajaran. Bandung: Sinar Baru Algensindo

Nana, et al.(2014). The Development Of Predict, Observe, Explain, Elaborate, Write, and Evaluate (Poe2we) Learning Model in Physics Learning At Senior Secondary School. Journal of Education and Practice, vol 5 (19), 56-65 
Munandar, Utami.(2009). Pengembangan Kreativitas Anak Berbakat. Jakarta : PT Rineka Cipta.

Mokhtarifar, Forouzan et al .(2014). Investigating The Relation Between Critical Thinking In The Dimensionof Creativity, Cognitive Maturity And Mental Involvement And The Religious Identity of Educational Sciences And Psychology Students of Isfahan University. Journal of education and practice, Vol 5(37) 93-103

Osdemir, Hakan.(2011). Effect Of Laboratory Activities Designed Based On Prediction-ObservationExplanation (POE) Strategy On Pre-Service Science Teachers' Understanding of Acid base Subject. Western Anatolia Journal of Educational Sciences (WAJES), ISSN 1308-8971, 169-174

Rivard L. P. Dan Straw, S. P. (2000). The Effect Of Talk And Writing On Learning Science: An Exploratory Study. Journal of Science Education, 84 (5), Pp.566-593.

Rustaman, Nuryani . (2005). Stategi Belajar Mengajar Biologi. Bandung : UPI

Sagala, Saiful . (2008). Konsep Dan Makna Pembelajaran.Bandung: Alfa Beta

Sardiman,A.M. (2007). Interaksi Dan Motivasi Belajar Mengajar. Jakarta: Raja Grafindo Persada

Samosir, Heppy. (2010). Model Pembelajaran Predict-ObserveExplain-Write (POEW) Untuk Meningkatkan Penguasaan Konsep Kalor Dan Keterampilan Berpikir Kritis Siswa SMA. Tesis PPS UPI Bandung: Tidak Diterbitkan

Slavin,Robert. (2008). Psikologi Pendidikan, Teori Dan Praktek. Bandung : Indeks

Saragih, Saat .(2014. The Improving of Problem Solving Ability and Students' Creativity Mathematical by Using Problem Based Learning in SMP Negeri 2 Siantar, Journal of education and practice, Vol 5(35), 123-132
Sardiman. (2004).Interaksi Dan Motivasi Belajar Mengajar. Jakarta: PT Raja Grafindo Persada

Suminar, Ratna .P. (2015. The Effectiveness Of TTW (Think-Talk-Write) Strategy In Teaching Writing Descriptive Text. Journal of English Language and Learning, vol 2 (2) 229-304

Sumirat, Ari.L. (2014) The Effectivenes Of A Cooperative Learning Strategy Think-Talk-Write Type On The Student's Compentence In Mathematical Communication And Disposition. Open Journal Training Dan Education, Vol 1(2), 1-10

Suparno, Paul. (2007) . Metodologi Pembelajaran Fisika: Konstruktivistik \& Menyenangkan. Yogyakarta: Universitas Sanata Dharma.

Suspriyati. Ninik.(2012). Pembelajaran Biologi Dengan Pendekatan Science, Environment, Technology, And Society (SETS) Menggunakan Model Problem Based Learning (PBL) Dan Model Predict, Observe, Explain, And Write (POEW) Ditinjau Dari Kreativitas Dan Motivasi Belajar Siswa”. (Studi Kasus Pembelajaran Biologi Materi Eubacteria Dan Archaeobacteria Siswa Kelas X Semester I Tahun Pelajaran 2011/2012 SMA Negeri 5 Surakarta). Tesis, Surakarta: Program Studi Pendidikan Sains Program Pasca Sarjana.

Usman, Moh Uzer. (2009). Menjadi Guru Profesional. Bandung: Remaja Rosdakarya.

Wartono Dkk . (2004). Materi Pelatihan Terintegrasi Sains. Jakarta : Depdiknas

Wah Liew, C. \& Treagust, D. 2004. The Effectiveness Predict - Observe Explain (POE) Technique In Diagnosing Studen's Understanding of Science And Identifying Their Level of Achievement 
INKUIRI: Jurnal Pendidikan IPA

P-ISSN : 2252-7893

Vol. 8, No. 1, 2019 (hal 81-93)

E-ISSN: 2615-7489

https://jurnal.uns.ac.id/inkuiri

DOI: 10.20961/inkuiri.v8i1.31820

Wenno I.H . (2008).Strategi Belajar Mengajar Sains Berbasis Kontekstual. Yogyakarta: Intimedia

Wulan, Rikhi .(2015). Improving Students' Mathematical Communication Through Scientific Approach And TTW (Think Talk Write). International journal of education. Vol 2(10), 35-46 